\title{
Kimmeridgian Foraminiferal Faunas of Northern Eurasia: Significance for Interregional Correlations and Palaeobiogeography
}

\author{
Clémentine Peggy Anne-Marie Colpaert1,2, Boris Leonidovich Nikitenko1,3 \\ ${ }^{1}$ Trofimuk Institute of Petroleum Geology and Geophysics, Siberian Branch of the Russian Academy of Sciences, Novosibirsk, \\ Russia \\ ${ }^{2}$ State Key Laboratory of Palaeobiology and Stratigraphy, Center for Excellence in Life and Environment, Nanjing Institute \\ of Geology and Palaeontology Chinese Academy of Sciences, Nanjing, China \\ ${ }^{3}$ Novosibirsk State University, Novosibirsk, Russia \\ Email: clementinecolpaert@gmail.com, NikitenkoBL@ipgg.sbras.ru
}

How to cite this paper: Colpaert, C.P.A.-M. and Nikitenko, B.L. (2019) Kimmeridgian Foraminiferal Faunas of Northern Eurasia: Significance for Interregional Correlations and Palaeobiogeography. Open Journal of Geology, 9, 573-576.

https://doi.org/10.4236/ojg.2019.910045

Received: August 15, 2019

Accepted: September 20, 2019

Published: September 23, 2019

Copyright ( 2019 by author(s) and Scientific Research Publishing Inc. This work is licensed under the Creative Commons Attribution International License (CC BY 4.0).

http://creativecommons.org/licenses/by/4.0/

(c) (i) Open Access

\begin{abstract}
Foraminifer is a very useful microorganism to perform biostratigraphical zonation of the Upper Jurassic. Foraminiferal biozones are calibrated by the ammonite standard zones and can be used for intra- and interregional correlations. Furthermore, the fossil record of foraminiferal faunas is well known among basins of the Northern Eurasia and is also used for accurate palaeoenvironmental, palaeobiogeographical, or biofacial reconstructions. It allows identifying a complex set of biotic and abiotic events which may be used to propose a more general palaeoecoloecological and palaeoceanographical reconstruction of the Subboreal, Boreal, and Arctic seas. Then, the late Kimmeridgian Northern Eurasian seas formed a network of well-connected palaeobasins during the sea-level rise and resulted in rather similar palaeoenvironmental conditions.
\end{abstract}

\section{Keywords}

Late Jurassic, Foraminifers, Palaeoceanography, Northern Eurasia

The study of the Upper Jurassic of the western part of Northern Asia and Europe dates back to the end of the 19th century. The biostratigraphical analyses were performed near the end of the 20th century. At that time, most of the micropalaeontological investigations across different regions of Europe and Western Siberia were performed separately. Various interpretations on the ob- 
served taxa by different authors resulted in problematic interregional correlations. The first generalized micropalaeontological investigation was performed by Kuznetsova [1], based on foraminiferal assemblages from different regions of western, eastern and northern Europe, as well as Siberia and Arctic Canada. This work introduces the occurrence of widely spread marker-species of the Kimmeridgian foraminiferal zone, which may be used for interregional correlations. In this way, recent studies based on foraminiferal assemblages from different regions of Northern Eurasia (Figure 1(a)) have shown that many of the previously described foraminifer species could be assigned to several single species, characterized by wide intraspecific variabilities [2] [3].

Then, the Kimmeridgian representatives of the genus Pseudolamarckina have shown that the East-European index-species Pseudolamarckina pseudorjasanensis was characterized by wide intraspecific variabilities and may encompass various previously described Kimmeridgian species of pseudolamarckiniids. The first appearance of $P$. pseudorjasanensis is recorded from the latest early Kimmeridgian of sub-Mediterranean and peri-Tethyan to Arctic regions [4] [5] (Figure 1(b)). Furthermore, it is recorded during the late Kimmeridgian together with a high number of widely distributed species. The Kimmeridgian foraminiferal $P$. pseudorjasanensis Zone appears to be an important interregional marker, which is used for the correlation of various widespread sections across Subboreal, Boreal and Arctic basins.

The composition of the upper Kimmeridgian foraminiferal associations of Northern Eurasia underlines the occurrence of two rather different assemblages

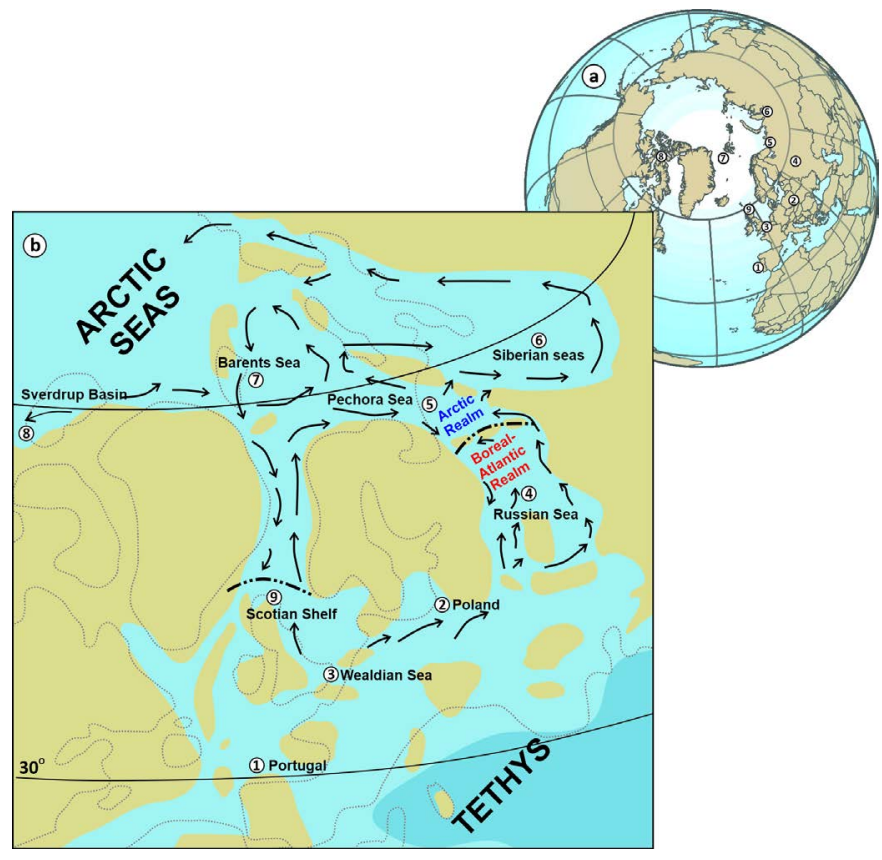

Figure 1. a. Geographical location of the studied regions of interest; b. Palaeobiogeographical and palaeoceanographical reconstructions of the Late Kimmeridgian North Eurasian seas. 
that respectively belong to the Boreal-Atlantic and the Arctic realms [6] (Figure 1(b)). Furthermore, some rare species of nodosariids, ceratobuliminiids and lituoliids are significant for biostratigraphical correlations, and are recorded from the Arctic to peri-Tethyan regions. This indicates good connections between the Kimmeridgian palaeobasins. During the Late Jurassic, the Subboreal to Boreal and southern Arctic regions were covered by shallow epeiric surface water, influenced by terrestrial inputs and restricted in seawater circulation [6]. The occurrence of common foraminiferal associations between regions of Western Europe and Western Siberia, as well as across the Greenland-Norwegian seaway indicates the periodic connections probably associated with changes of sea-level and palaeoceanographical conditions (Figure 1(b)). The Subboreal Western European Sea was probably affected during the Late Jurassic by northern cold-water inputs, interpreted to have flowed southward through the western side of the Greenland-Norwegian Seaway along the coast of the Greenland and Canada territories. On the other hand, a warm water current was characterized by southwest to northeast orientation and probably favored the migration of typical taxa of the Boreal-Atlantic Realm [3] [4] [5] [6] [7].

\section{Acknowledgements}

Financial support from the Russian Science Foundation (18-17-00038), the Strategic Priority Research Program of Chinese Academy of Sciences (XDB26000000), and by the National Natural Science Foundation of China (41572006, 41688103, 41972007). This is a contribution to UNESCO/IUGS/IGCP 679.

\section{Conflicts of Interest}

The authors declare no conflicts of interest regarding the publication of this paper.

\section{References}

[1] Kuznetsova, K.I. (1979) Late Jurassic Stratigraphy and Palaeobiogeography of the Boreal Realm Based on Foraminifers (Stratigrafiya i paleobiogeografiya pozdney yury Boreal'nogo poyasa po foraminiferam). NAUKA, Moscow. (In Russian)

[2] Nikitenko, B.L. (2009) Stratigraphy, Paleobiogeography and Biofacies of the Jurassic of Siberia Based on Microfaunas (Foraminifera and Ostracods) [Stratigrafiya, paleobiogeografiya i biofatsii yury Sibiri po mikrofaune (foraminifery i ostrakody)]. Parallel, Novosibirsk, 675. (In Russian with Extended English Summary)

[3] Colpaert, C.P.A.-M. and Nikitenko, B.L. (2019) Pseudolamarckina pseudorjasanensis Dain, 1967 (Foraminifera) as a Kimmeridgian Marker Species and Its Significance to Biostratigraphy, Palaeoecology, and Palaeobiogeography. Polar Research, 38, 3461. https://doi.org/10.33265/polar.v38.3461

[4] Hedinger, A. (1993) Upper Jurassic (Oxfordian-Volgian) Foraminifera from the Kusky Formation, Aklavik Range, District of MacKenzie, Northwest Territories. Geological Survey of Canada, Bulletin 439. https://doi.org/10.4095/41746

[5] Nikitenko, B.L., Knyazev, V.G., Pestchevitskaya, E.B. and Glinskikh, L.A. (2015) The Upper Jurassic of the Laptev Sea: Interregional Correlations and Paleoenvi- 
ronments. Russian Geology and Geophysics, 56, 1173-1193.

https://doi.org/10.1016/j.rgg.2015.07.008

[6] Holmden, C., Creaser, RA., Muehlenbachs, K.I.S.A., Leslie, S.A. and Bergström, S.M. (1998) Isotopic Evidence for Geochemical Decoupling between Ancient Epeiric Seas and Bordering Oceans: Implications for Secular Curves. Geology, 26, 567-570. https://doi.org/10.1130/0091-7613(1998)026<0567:IEFGDB>2.3.CO;2

[7] Colpaert, C., Pestchevitskaya, E.B. and Nikitenko, B.L. (2017) Upper Jurassic Foraminifera, Dinoflagellates and Terrestrial Sporomorphs from the Gorodishche Section (Ul'yanovsk Region, East European Platform, Russia): Biostratigraphic, Palaeoenvironmental and Palaeobiogeographical Implications. Revue de Micropaléontologie, 60, 549-572. https://doi.org/10.1016/j.revmic.2017.10.001 